\title{
Sustained Release Oral Liquid Dosage Form
}

National Cancer Institute

\section{Source}

National Cancer Institute. Sustained Release Oral Liquid Dosage Form. NCI Thesaurus.

Code C69044.

A solution or suspension intended for oral administration and designed to release active and/or inert ing redient(s) slowly so as to achieve a constant circulating concentration of the ing redient over a period of time. 